\title{
Differentiation of ecological niches of the forest-forming species in the Caucasus
}

\author{
Rustam Pshegusov*, Fatimat Tembotova, Yulia Sablirova, Malika Mollaeva, Anzor Akhomgotov \\ Tembotov Institute of Ecology of Mountain Territories of Russian Academy of Science, 360051 Nalchik, Russia
}

\begin{abstract}
Adaptations of Abies nordmanniana, Picea orientalis, Pinus sylvestris, Fagus orientalis, and Carpinus betulus to the abiotic environmental conditions of the study area largely determined their predicted distribution in the Caucasus. The ecological niches of the species mostly coincided in two analyzed complex environmental factors (characteristics of water regime and topographic parameters). The complex humidity factor was the main factor determining the potential distribution the forest-forming species in the Caucasus $(65 \%$ of the contribution in the Maxent models). Topographic ENVIREM predictors were also significant in the species distribution $(20 \%$ of the contribution in the models). Abies nordmanniana and Fagus orientalis were the most sensitive to the humidity factor, while Pinus sylvestris depended largely on the topographic factors. The similarity of the distribution potential of the studied species in the Caucasus was explained largely by a high degree of overlap of ecological niches (Schoener's $D=0.55-0.79$ ) and their visual overlap in the orthogonal space of the analyzed ecological factors. The largest Schoener's D indexes were observed for the pairs Pinus sylvestris - Picea orientalis, Abies nordmanniana - Picea orientalis, Fagus orientalis - Picea orientalis, and Fagus orientalis - Carpinus betulus. Carpinus betulus, Fagus orientalis and Pinus sylvestris had the widest ecological niches.
\end{abstract}

\section{Introduction}

Identification of the main factors affecting the distribution of forest-forming tree species is important for understanding the general patterns of their spatial distribution, identification and protection of the most vulnerable areas, forest management and rational use of forest resources. Significant progress in this direction was closely related to the methods of modeling the potential suitability of habitats, such as Ecological niche modeling (ENM). ENM methods are the most effective for estimating the species spatial and temporal distribution $[1,2]$. These methods aim to identify the abiotic and biotic components of the species ecological niches, thereby determining the spatial distribution of suitable habitats for the species [3, 4].

In ENM, methods that use data on the presence of species (presence points) are more preferable then methods that also use data on the absence of species in the study area [4-6]. An effective method for ecological niche modeling only by presence points is Maxent (Maxent software for species habitat modeling), which constructs accurate predictive models [5, 7-10]. Maxent estimates the distribution of probabilities of species occurrences by distributions of environmental variable values similar to the habitat sites in which the species were found. The habitats identified with the highest probability of species occurrence are considered the most suitable.

The developing field of ENM is the quantitative comparison of ecological niches and assessment of their differentiation for sympatric species within the single range. Effective quantitative indicators of the width and overlap degree of ecological niches are Levins' B and Schoener's D, respectively $[11,12]$. Such studies are relevant for the main forest-forming species of the Caucasus, which are Abies nordmanniana (Steven) Spach, Picea orientalis (L.) Peterm. и Pinus sylvestris L., Fagus orientalis Lipsky, and Carpinus betulus L. These dominant species largely determine the structure, species composition, and dynamic of the mountain forest ecosystems in the Caucasus. They are also of great economic importance and high conservation value for the region. We studied monodominant highly productive forest stands of Abies nordmanniana, Picea orientalis, Pinus sylvestris, Fagus orientalis, and Carpinus betulus, as the most stable plant communities existing under optimal environmental conditions for the species. Using such plant communities as species occurrence data in the ENM increases the probability of species being found in the predicted area.

Therefore, the aim of this study was to identify the abiotic components of ecological niches of the main forest-forming species in the Caucasus and to assess the differentiation of ecological niches by their width and degree of overlap. We assume that the similarity or differences in the spatial distribution of the studied species in the Caucasus are largely due to the similarity or difference in the abiotic components and the quantitative parameters of their ecological niches. 


\section{Materials and methods}

\subsection{Study area}

The field of research covered the Caucasian mountain country (between $39^{\circ}-47^{\circ} \mathrm{N}$ and $35^{\circ}-50^{\circ}$ E) in the following physical and geographical boundaries: in the east, along the coast of the Caspian Sea; in the north, from the Caspian Sea along the Kumo-Manych Depression and further along the northern border of Krasnodar Krai to the Black Sea; in the west, along the Black Sea coast; and in the south, by the borders of Georgia, Armenia, and Azerbaijan with Turkey and Iran (Figure 1). The total area of the analyzed territory amounted to thous. $\mathrm{km}^{2}$. Within the Russian Caucasus the territory of the Kabardino-Balkar Republic, Krasnodar Krai, the Republic of Adygea, Stavropol Krai, the Republic of Dagestan, the Chechen Republic, the Republic of Ingushetia, the Karachay-Cherkess Republic, the Republic of North Ossetia-Alania, and the Republic of Abkhazia were studied.

The study area included the Kubanskiy variant of vertical zonation of the Western North Caucasus zonality type (Western Caucasus), as well as the Elbrusskiy and Terskiy variants of the vertical zonation of the Eastern North Caucasus zonality type (most of the Central Caucasus and Eastern Caucasus, respectively) [13]. The gradient belt of the Western North Caucasus zonality type is a barrier-sectoral variation of the steppe belt type, influenced by the littoral foothills of the Caspian basin. The increased humidification of the region is caused due to the influence of the Black Sea-Mediterranean cyclones and the proximity of the Atlantic Ocean. Thus, a humid subtropical climate characterizes the southern macroscline of the Western Caucasus. The average annual temperature here is $+14.5^{\circ} \mathrm{C}$, and the average annual precipitation is $1350 \mathrm{~mm}$ and more. The northern macroslope of the Western Caucasus is characterized by a humid climate with an average annual precipitation of 500-900 mm.

The Greater Caucasus mountain range blocks the influence of wet Black Sea-Mediterranean cyclones within the Elbrusskiy variant of vertical zonation. Dry winds of the Caspian lowland and the glaciation of the Central Caucasus highlands cause dryness and continentality of the climate, xerophytization of landscapes, the wide steppification of the subalpine and alpine belts, as well as the loss of the dark coniferous forest belt and broad-leaved forest belt in the Elbrusskiy variant of vertical zonation.

Increasing heights of the front Caucasian mountain ridges strengthens their barrier role on the way of the dry winds from the Caspian Sea within the boundaries of the Terskiy variant of vertical zonation. Broad-leaved forests are widely distributed here, as in the Kubanskiy variant of vertical zonation, but they are arider. Just as in the Elbrusskiy variant of vertical zonation, in the Eastern Caucasus there is no belt of dark coniferous forests. On more arid slopes, there are local stands of pine forests.

The climate of the Central and Eastern Caucasus is relatively hot, dry continental in the plains, and relatively cold, humid continental in the mountainous regions.

\subsection{Studied species}

Abies nordmanniana is a decorative species widely used in Europe for the production of "Christmas trees", which are sold annually in the amount of about 42 million trees [14]. Accordingly, a significant part of Abies nordmanniana studies is aimed at reproduction of the species and preservation of decorative effect of trees in culture [14, 15-18]. The literature resources present few data on the species in the natural conditions of the native range limited to the territory of the Russian Caucasus, Georgia and the north-eastern regions of Turkey [19].

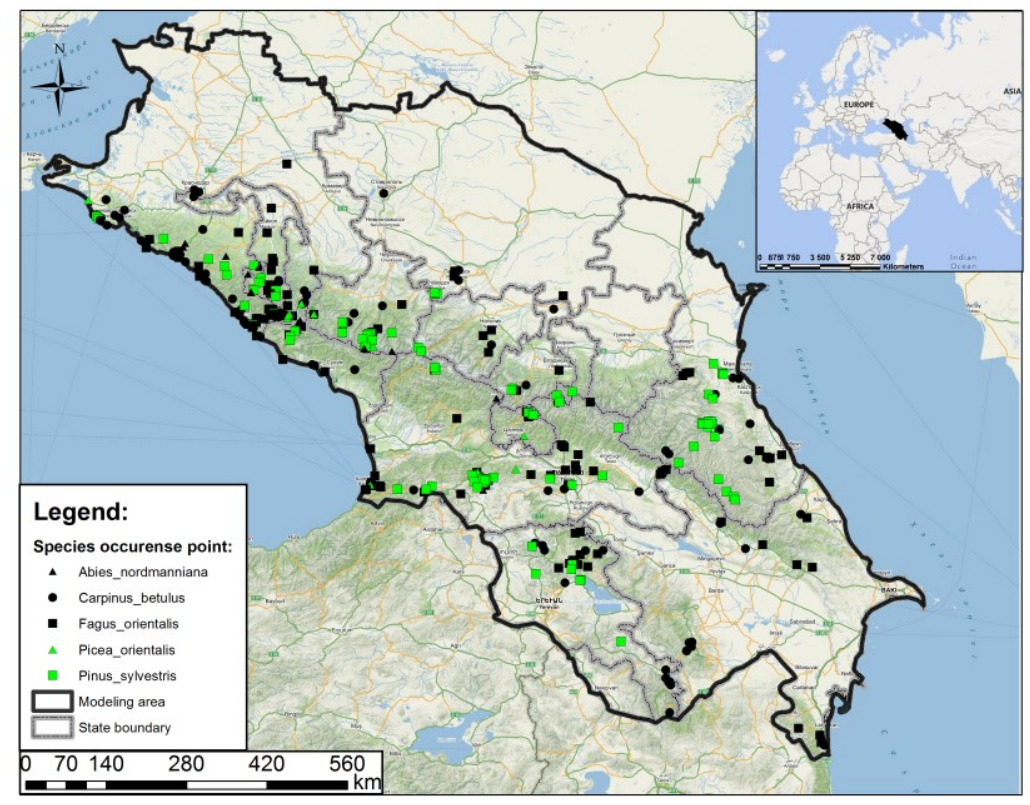

Fig. 1. Location and schematic map of the study area. Presence points of the studied species 
In Turkey, where fir forests occupy about $2.62 \%$ of the country's forested area (584.87 ha) [20], an analysis of their species richness and spatial structure was carried out [20-22]. Studies of Caucasian populations of Abies nordmanniana are concentrated in the Western Caucasus, where the main fir forests are located. The main territories are the basins of the Pshekh, Belaya, Laba rivers on the northern macroslope of the Greater Caucasus and the upper reaches of the Mzymta, Psou, Bzych, Rioni rivers on the southern macroslope [23, 24]. The researchers noted the vulnerability of the Caucasus fir forests as a result of the negative anthropogenic (deforestation), climatic and biotic (mass bacterial diseases) impacts $[24,25]$. At the same time, the main research fields of the last two decades were dendrochronology [26], the climate-driven changes in the altitude boundaries of the species [24], forest restoration [27], mapping of dark coniferous forests with Abies nordmanniana $[28,29]$.

The natural range of Picea orientalis is also mainly limited to the territory of the Russian Caucasus, Georgia, and the Eastern Black Sea region of Turkey $[23,30]$. In the mountainous regions of Turkey, the distribution of spruce forests is positively correlated with the altitude, the slope steepness and the distance to the sea [31]. In the Western Caucasus, Picea orientalis forests occupy no more than $5 \%$ of the forested area, mainly in the eastern regions, where they spread along the lower parts of the slopes and river terraces up to 1500-1700 $\mathrm{m}$ above sea level [23]. Current studies of the Turkish populations of the species aimed at their genetic diversity [32, 33], the structure of forest stands [34], and modeling of spatial distribution [35].

Mapping of spruce forests using GIS technologies was also carried out in the North-Western Caucasus [28, 29]. Researchers have established the degradation of spruce forests throughout the entire range of Picea orientalis, one of the main reasons for which are outbreaks of beetles Ips typographus (Linnaeus 1758) and Dendroctonus micans (Kugelann 1794) against the background of climatic changes and the general weakening of mainly single-aged forest stands [34, 3638].

Pinus sylvestris is a widespread species in Eurasia. Ecological plasticity, genetic variability, and the great economic importance of this species determine the variety of directions in the study of its biology and ecology. Previously, several two-coniferous species of the genus Pinus L. were identified for the Caucasus, but subsequent studies of their genetic differentiation from Eastern European populations of Pinus sylvestris [39] their belonging to Pinus sylvestris system (with the exception of Pinus eldarica Medw. in Georgia and Pinus pityusa Steven on the Black Sea coast). A wide ecological range of Caucasian light coniferous forests by ecological gradients and underlying rocks determines a high typological diversity of pine forests [40], but in the central part of the Caucasus, Pinus sylvestris forms mainly monodominant forest stands. Morphological variability of the species pollen [41], reproductive phenological isolation and genetic variability of Pinus sylvestris populations were studied for the Central Caucasus [42, 43]. The mapping of pine forests of certain regions was also carried out here [43].

Broad-leaved forests of Fagus orientalis Lipsky covers the Greater and Lesser Caucasus, Crimea, Turkey, Northern Iran, Bulgaria, Greece, and Syria up to $2100 \mathrm{~m}$ above sea level $[44,45]$. The refuge for Fagus orientalis during the Last Glacial Maximum was Northern Turkey and the Western Caucasus, as well as Northern Iran [46]. A drier climate and higher temperatures against the background of climate change will probably limit the spread of this species in the future [46].

Small-medium deciduous tree species Carpinus betulus L. covers Asia Minor, the Iranian plateau, mainland Europe, the Caucasus, and Transcaucasia. The most suitable habitats for Carpinus betulus within the boundaries of the modern territory of Anatolia and its surroundings in the Last glacial Maximum were the Black Sea region and Western Anatolia according to the modeling of the potential distribution of the species [47]. In the future, the range of Carpinus betulus may shift to the north [47], where the Black Sea coast of the Caucasus is located.

\subsection{Species occurrence data and environmental variables}

Species occurrence data were sourced from the expedition research in 2012-2020 and the Global Biodiversity Information Facility (GBIF). A total of 520 species occurrence records were used in the analysis (Table 1). We used the set of climatic and topographic environmental variables from the ENVIREM dataset [48]. Many of ENVIREM variables are directly related to the ecological or physiological processes of plant species [49].

Table 1. Species occurrence data used in the study

\begin{tabular}{|l|c|c|c|}
\hline \multicolumn{1}{|c|}{ Species } & $\begin{array}{c}\text { DOI from } \\
\text { the GBIF }\end{array}$ & $\begin{array}{c}\text { GBIF records/ } \\
\text { after filtering }\end{array}$ & $\begin{array}{c}\text { Expedition } \\
\text { records }\end{array}$ \\
\hline $\begin{array}{l}\text { Abies } \\
\text { nordmanniana }\end{array}$ & $10.15468 / \mathrm{dl} . \mathrm{v} 2 \mathrm{ff} 6 \mathrm{j}$ & $497 / 52$ & 17 \\
\hline $\begin{array}{l}\text { Carpinus } \\
\text { betulus }\end{array}$ & $10.15468 / \mathrm{dl} . \mathrm{a} 4 \mathrm{yhh} 3$ & $1967 / 114$ & 23 \\
\hline $\begin{array}{l}\text { Fagus } \\
\text { orientalis }\end{array}$ & $10.15468 / \mathrm{dl} . z v h j \mathrm{hs}$ & $3009 / 105$ & 42 \\
\hline $\begin{array}{l}\text { Picea } \\
\text { orientalis }\end{array}$ & $10.15468 / \mathrm{dl} . \mathrm{dkaz3a}$ & $194 / 32$ & 12 \\
\hline $\begin{array}{l}\text { Pinus } \\
\text { sylvestris }\end{array}$ & $10.15468 / \mathrm{dl} . \mathrm{ymbrx} 9$ & $147 / 108$ & 15 \\
\hline
\end{tabular}

\subsection{Modeling and model evaluation}

The data of environmental variables of the study area were extracted using raster package in R. The matrix of extracted values was analyzed by the factor analysis (principal component method, PCA) using the FactoMine R package in $R$ [50]. The obtained eigenvalues of the main axes (factors) of the PCA combined the ENVIREM variables selected on the basis 
of non-collinearity and contribution to the construction of the model. These axes (complex factors) were visualized in the $\mathrm{R}$ using the ggplot2 package in $\mathrm{R}$. With the KDE (Kernel density estimation) method, the ecological niches of species were mapped as agglomerations of points in the orthogonal space of pairs of PCA axes. This method allowed us to visually compare the ecological niches of the studied species in the Caucasus.

The eigenvalues of the factors (the first three orthogonal axes of PCA) were used as layers in Maxent modeling. The analysis of replicated Maxent models (the ENMtools package in R [51]) was used for quantitative comparison and evaluation of the species ecological niches differentiation by their width (Levins' B) and the overlap (Schoener's D) [11, 12].

The quality of the models was evaluated by the values of the AUC (Area under the curve). AUC indicates the results of statistical analysis of the coincidence of models constructed from test and training data (evaluation of the model accuracy). The optimal AUC values for reliable models should be close to 1 or at least should be higher than 0.5 (50\% threshold of habitat suitability).

\section{Results}

\subsection{Ecological niche modeling}

PCA revealed three main components with cumulative variation of $91.1 \%$ (Table 2 ).

Table 2. Results of factor analysis (PCA, Varimax normalized) of environmental variables of the study area

\begin{tabular}{|l|c|c|c|}
\hline \multirow{2}{*}{ Variables } & \multicolumn{3}{c|}{ PCA factors } \\
\cline { 2 - 4 } & Factor 1 & Factor 2 & Factor 3 \\
\hline annualPET, mm/year & $\mathbf{0 . 8 0}$ & 0.48 & 0.22 \\
\hline ariditylndexThornthwaite & 0.37 & $\mathbf{- 0 . 8 2}$ & 0.36 \\
\hline climaticMoisturelndex & -0.26 & $\mathbf{0 . 9 1}$ & -0.25 \\
\hline continentality, ${ }^{\circ} \mathrm{C}$ & 0.00 & $\mathbf{- 0 . 7 7}$ & 0.57 \\
\hline embergerQ & 0.03 & $\mathbf{0 . 9 6}$ & -0.14 \\
\hline growingDegDays0 & $\mathbf{0 . 8 7}$ & 0.17 & 0.42 \\
\hline growingDegDays5 & $\mathbf{0 . 8 8}$ & 0.14 & 0.40 \\
\hline maxTempColdestMonth,${ }^{\circ} \mathrm{C} \times 10$ & $\mathbf{0 . 9 5}$ & -0.05 & 0.22 \\
\hline minTempWarmestMonth, ${ }^{\circ} \mathrm{C} \times 10$ & 0.67 & 0.34 & 0.64 \\
\hline monthCountByTemp10, months & $\mathbf{0 . 7 2}$ & 0.26 & 0.57 \\
\hline PETColdestQuarter, mm/month & $\mathbf{0 . 9 6}$ & 0.04 & -0.12 \\
\hline thermInd, ${ }^{\circ} \mathrm{C}$ & $\mathbf{0 . 8 0}$ & 0.32 & 0.50 \\
\hline topoWet & 0.22 & 0.41 & $\mathbf{0 . 8 5}$ \\
\hline TRI & -0.30 & -0.37 & $\mathbf{- 0 . 7 3}$ \\
\hline Eigenvalue & 13.71 & 4.04 & 2.01 \\
\hline Explained variance, $\%$ & 65.25 & 20.12 & 5.77 \\
\hline
\end{tabular}

Marked loadings are $>0.7$; the names and units of measurement of the ENVIREM variables are given by Title and Bemmels [49].

The first main axis (about $65 \%$ of variables variance) was mainly formed by seven predictors. Five predictors were the temperature variables: growingDegDays0 and growingDegDays5 (the sum of the average monthly temperature for the months with an average temperature above 0 and $5^{\circ} \mathrm{C}$, respectively, multiplied by the number of days), maxTempWarmestMonth (the maximum temperature of the warmest month), monthCountByTemp10 (the number of months during which the average air temperature exceeds $10^{\circ} \mathrm{C}$ ), and thermInd (the index of compensated thermality, depending on the sum of the average annual temperature range, minimum and maximum temperatures of the coldest month). Two highly correlated variables of the first axis were potential evapotranspiration characteristics, indicating the maximum amount of moisture evaporated by plants from the unit of reference surface in the absence of moisture deficiency. They were annualPET (the average annual protentional evapotranspiration) and PETColdestQuarter (the average monthly protentional evapotranspiration for the coldest quarter). Evapotranspiration depends on solar radiation, air temperature, and wind speed, as well as on the frequency of precipitation in the region [11].

The main variables of the second PCA axis characterized the water regime of the study area. They were aridityIndexThornthwaite (the Thornthwaite aridity index of climate), climaticMoistureIndex (the index of relative humidity and aridity of the climate), embergerQ (the Emberger's pluviothermic quotient associated with the annual potential evapotranspiration and extreme annual thermal amplitude). Continentality of the climate, in addition to the annual temperature range, also characterizes the amount of precipitation in the region. The indicator increases with the increasing dryness of the climate.

The third PCA axis combined topographic parameters. They were Terrain roughness index TRI (the index of terrain roughness, which quantifies local vertical topographic heterogeneity by calculating the average elevation difference between a particular site and its eight neighbor sites [53]) and topoWet (the topographic humidity index used to study the moisture level of substrates in different parts of the slopes in the mountains [54]).

We assessed the contribution of PCA factors to the Maxent models of the species distribution. Based on AUC values, all Maxent models had adequate values: the AUCs showed good values for the training and test models, and AUCDiff (difference between training and test AUC data) were low (Table 3).

Table 3. Evaluation of Maxent models of the studied species distribution in the Caucasus

\begin{tabular}{|l|c|c|c|}
\hline \multicolumn{1}{|c|}{ Species models } & AUCTrain \pm SD & AUCTest \pm SD & AUCDiff \\
\hline Abies nordmanniand & $0.94 \pm 0.005$ & $0.92 \pm 0.016$ & 0.02 \\
\hline Carpinus betulus & $0.89 \pm 0.006$ & $0.87 \pm 0.026$ & 0.02 \\
\hline Fagus orientalis & $0.87 \pm 0.010$ & $0.86 \pm 0.044$ & 0.01 \\
\hline Picea orientalis & $0.93 \pm 0.006$ & $0.92 \pm 0.029$ & 0.01 \\
\hline Pinus sylvestris & $0.88 \pm 0.003$ & $0.86 \pm 0.011$ & 0.02 \\
\hline
\end{tabular}

In terms of percentage contribution and permutation importance, the largest percentage contribution to the Maxent models of Abies nordmanniana, Picea orientalis, Fagus orientalis, and Carpinus betulus distribution was made by Factor 2 (Table 4). As shown above, it combined Thornthwaite aridity index and the 
climate continentality with negative factor loads, as well as the index of relative humidity and Emberger's pluviothermic quotient with positive factor loads.

Table 4. Contribution of PCA factors to the distribution of the studied species in the Caucasus

\begin{tabular}{|l|c|c|c|c|c|c|}
\hline \multirow{2}{*}{ Species } & \multicolumn{5}{|c|}{ Contribution of PCA factors } \\
\cline { 2 - 7 } & \multicolumn{2}{|c|}{ Factor 1 } & \multicolumn{2}{c|}{ Factor 2 } & \multicolumn{2}{c|}{ Factor 3 } \\
\cline { 2 - 7 } & PC, \% & PI, \% & PC, \% & PI, \% & PC, \% & PI, \% \\
\hline Abies nordmanniana & 9.7 & 6.5 & 65.2 & 75 & 19.1 & 11.5 \\
\hline Picea orientalis & 16.2 & 30.6 & 42.5 & 34.9 & 33 & 28 \\
\hline Pinus sylvestris & 13.9 & 19.5 & 27.4 & 25.8 & 39.8 & 32.7 \\
\hline Fagus orientalis & 7.1 & 6.6 & 56.3 & 37.9 & 32.4 & 50.7 \\
\hline Carpinus betulus & 17.4 & 16.2 & 41.9 & 20.5 & 29.6 & 43.6 \\
\hline
\end{tabular}

PC: percent contribution - the contribution of the PCA factor to the construction of the Maxent model; PI: permutation impotance - permutation coefficient.

As shown above, it combined Thornthwaite aridity index and the climate continentality with negative factor loads, as well as the index of relative humidity and Emberger's pluviothermic quotient with positive factor loads. Accordingly, Factor 2 can be characterized as a factor of the moisture availability of the species habitats in the Caucasus. Abies nordmanniana and Fagus orientalis were the most sensitive to the humidity factor, while Pinus sylvestris depended on the moisture availability of habitats to the least degree.

The second most important PCA Factor 3 was the complex topographic factor, which included the Terrain roughness index and the topographic humidity index. The first indicator, which increases with increasing the slope steepness, was characterized by a negative factor loading, while the second indicator positively correlated with Factor 3. Accordingly, the most suitable habitats for Pinus sylvestris, Picea orientalis, Fagus orientalis, and Carpinus betulus with Factor 3 contribution of $30-40 \%$ in Maxent models are non-steep slopes with moist soils. Temperature Factor 1, despite explaining most of the environmental variability of the study area, was of the least importance in the species distribution.

\subsection{Differentiation of ecological niches}

Visualization of the species ecological niches using the KDE method showed their weak differentiation along the second and third main axes of PCA (humidity Factor 2 and topographic Factor 3) (Figure 2). The confirmation was the high (according to Rödder and Engler [55]) values of Schoener's D index indicating the degree of overlap of ecological niches (Table 5). At the same time, ecological niches overlap to the greatest extent in the humidity factor for the pairs Fagus orientalis - Carpinus betulus, Abies nordmanniana - Picea orientalis, and Pinus sylvestris - Picea orientalis. In the topographic factor, the most significant overlap of ecological niches for the pairs Abies nordmanniana - Picea orientalis, Fagus orientalis - Carpinus betulus, and Fagus orientalis - Abies nordmanniana. A significant overlap of the ecological niches of the studied species in the Caucasus was also observed along the first axis of the PCA, which mainly combined the temperature variables
(Figure 2). The range of values of these variables was more similar for Fagus orientalis and Carpinus betulus, Pinus sylvestris and Picea orientalis, and Fagus orientalis and Abies nordmanniana.

Table 5. Values of ecological niche overlap index Schoener's $\mathrm{D}$ for the studied species in the Caucasus

\begin{tabular}{|l|c|c|c|c|c|}
\hline Species & $\begin{array}{c}\text { Abies } \\
\text { nordman. }\end{array}$ & $\begin{array}{c}\text { Picea } \\
\text { orientalis }\end{array}$ & $\begin{array}{c}\text { Pinus } \\
\text { sylvestris }\end{array}$ & $\begin{array}{c}\text { Fagus } \\
\text { orientalis }\end{array}$ & $\begin{array}{c}\text { Carpinus } \\
\text { betulus }\end{array}$ \\
\hline $\begin{array}{l}\text { Abies } \\
\text { nordman. }\end{array}$ & 1 & 0.79 & 0.68 & 0.72 & 0.55 \\
\hline $\begin{array}{l}\text { Picea } \\
\text { orientalis }\end{array}$ & - & 1 & 0.79 & 0.79 & 0.63 \\
\hline $\begin{array}{l}\text { Pinus } \\
\text { sylvestris }\end{array}$ & - & - & 1 & 0.74 & 0.64 \\
\hline $\begin{array}{l}\text { Fagus } \\
\text { orientalis }\end{array}$ & - & - & - & 1 & 0.78 \\
\hline $\begin{array}{l}\text { Carpinus } \\
\text { betulus }\end{array}$ & - & - & - & - & 1 \\
\hline
\end{tabular}

In general, the largest overlaps of ecological niches according to the Schoener's D index were observed for the pairs Pinus sylvestris - Picea orientalis, Abies nordmanniana - Picea orientalis, Fagus orientalis Picea orientalis, and Fagus orientalis - Carpinus betulus. Thas the ecological niche of Picea orientalis significantly overlapped with the ecological niches of other studied species with the exception of Carpinus betulus. Carpinus betulus was the most ecologically isolated tree species from other forest-forming species with the exception of Fagus orientalis.In accordance with the Levins' B index the broad-leaved species Carpinus betulus and Fagus orientalis, as well as the light coniferous species Pinus sylvestris had the widest ecological niches (the average value of Levins' B were $0.42,0.38$ and 0.38 , respectively) (Figure 3). The dark coniferous tree species Abies nordmanniana and Picea orientalis had a much smaller ecological range of suitable habitat conditions (the average value of Levins' $\mathrm{B}$ were 0.23 and 0.28 , respectively). Fagus orientalis and Pinus sylvestris were the most similar to each other in the average values of Levins' B.

\section{Discussion}

\subsection{Ecological niche modeling}

The purpose of this study was to assess the differentiation of ecological niches of the main forestforming species of the Caucasus by their abiotic components. We revealed a significant effect of the humidity and topographic complex factors on the distribution of Abies nordmanniana, Picea orientalis, Fagus orientalis, Carpinus betulus and Pinus sylvestris, Fagus orientalis, Picea orientalis, Carpinus betulus, respectively.

These results are in line with Shevchenko and Geraskina [29], who observed that the amount of precipitation in the driest month and the altitude above sea level made the largest contribution in the distribution 
models of Abies nordmanniana and Picea orientalis in the North-Western Caucasus. The authors also showed that the amount of precipitation in the driest month (as
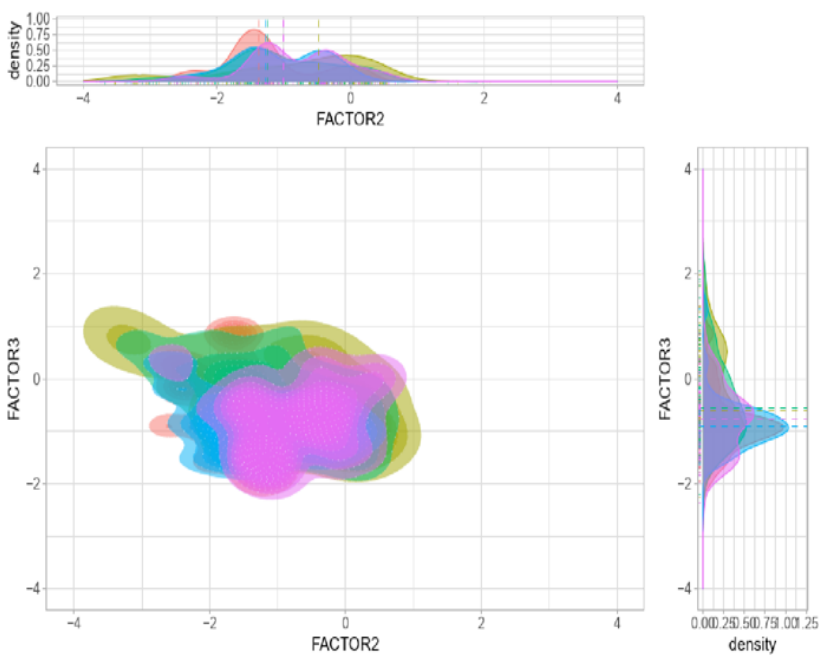

Species 1 Abies_nordmanniana

Carpinus_betulus

Fagus_orientalis Picea_orientalis Pinus_sylvestris well as the temperature seasonality) affected the current distribution of Fagus orientalis in the region.
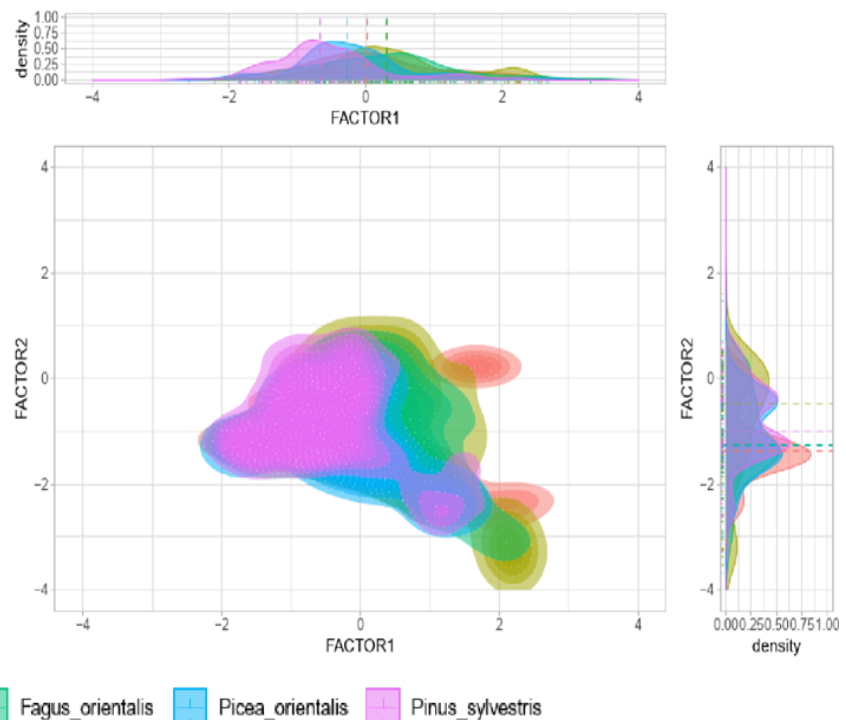

PCA)

In our studies, Pinus sylvestris was least dependent on air humidity. Like Fagus orientalis, Picea orientalis, Carpinus betulus, this species mainly depended on the topographical factor, preferring non-steep slopes with moist soils. Usta and Y1lmaz [31] also found that slope steepness and altitude above sea level negatively correlated with the distribution of Pinus sylvestris and Carpinus orientalis on the Karadağ Mass, Turkey. At the same time, the researchers [31] concluded that slope steepness and altitude positively correlated with the distribution of Fagus orientalis and Picea orientalis, which may be due to climatic differences in the studied territories. They also reported about drought resistance of Pinus sylvestris [31].

Rakhmatullina et al. [57] used the Maxent models to analyze the contribution of environmental factors to the distribution of Pinus sylvestris monodominant forest on one of the uplands of the Republic of Bashkortostan, Southern Ural, Russia. They revealed a significant influence of the maximum temperature of the warmest month (suitable values of $25-26.5^{\circ} \mathrm{C}$ ) on the Pinus sylvestris distribution in the region, which also may be due to climatic differences between the Southern Ural uplands and the Caucasus Mountains. At the same time, the second significant factor that made a great contribution to the Maxent models of Pinus sylvestris distribution was, as in our study, the topographic humidity index [57]. This confirms the importance of the topographic factor in the distribution of the species. Isaev et al. [58] also emphasized the significant contribution of temperature factors to the formation of the Pinus sylvestris area in the lowlands on the example of the Republic of Sakha (Yakutia).

\subsection{Differentiation of ecological niches}


According to our study, the ecological niches of the studied species largely overlapped. In the humidity factor, the ecological niches of Fagus orientalis and Carpinus betulus, Abies nordmanniana and Picea orientalis, as well as Pinus sylvestris and Picea orientalis overlapped to the greatest extent. In the topographical factor, the most significant overlaps of ecological niches were for the pairs Abies nordmanniana - Picea orientalis, Fagus orientalis - Carpinus betulus, as well as Fagus orientalis - Abies nordmanniana. The largest overlaps according to the Schoener's D index were observed for Fagus orientalis - Carpinus betulus, Abies nordmanniana - Picea orientalis, Pinus sylvestris - Picea orientalis, and Fagus orientalis - Picea orientalis. Carpinus betulus, Fagus orientalis and Pinus sylvestris had the widest ecological niches, while Abies nordmanniana and Picea orientalis had much smaller ecological niches.

Our results are consistent with Shevchenko and Geraskina [29], which observed that in the NorthWestern Caucasus, according to the Maxent modeling results, the areas of Abies nordmanniana and Picea orientalis completely coincide. The authors concluded that the difference in the real distribution of the two species in the region is largely due to the anthropogenic factor (deforestation) and the higher regenerative capacity of Abies nordmanniana.

Coban [20] noted that in the Northwest of Turkey, fir-beech forests occurred at 1000-1400 m above sea level, and only above $1400 \mathrm{~m}$ were pure fir forests found. The author concluded that shade tolerance of both species provided a high degree of tree spatial mixing in fir-beech co-dominated forest [20]. Komin [26] obtained similar results in the North-Western Caucasus. The author showed that in the North-Western Caucasus, firbeech forests occurred at 800-1200 m above sea level, while forests with a predominance of fir were found above $1200 \mathrm{~m}$ above sea level. These results confirm a significant degree of overlap of ecological niches of Abies nordmanniana and Fagus orientalis. Komin [26] also noted that in the subalpine belt of North-Western Caucasus, Abies nordmanniana forms mixed forest stands with Picea orientalis. Komarova et al. [28] showed that in the same region, Fagus orientalis and Picea orientalis were often found in the fir forests. Litvinskaya and Salina [23] also emphasized the ecological similarity of Abies nordmanniana, Picea orientalis and Fagus orientalis in the Western Caucasus.

Our results are also in line with Jensen et al. [59], who studied the potential distribution of Carpinus betulus in Denmark and the competition of the species with Fagus orientalis. The authors found a significant negative correlation at the local distribution of Carpinus betulus and Fagus orientalis, which confirms the significant competition between the species and the similarity of their ecological niches.

\section{Conclusions}

The analysis of the main abiotic predictors that determined the potential distribution of the studied species in the Caucasus showed the dependence of their potential distribution on the humidity and topographic factors. Humidity complex factors (the Thornthwaite aridity index, the climate continentality, the index of relative humidity, and the Emberger's pluviothermic quotient) mainly affected the distribution of Abies nordmanniana, Picea orientalis, Fagus orientalis, Carpinus betulus. Topographic complex factor (the index of terrain roughness, the topographic humidity index) was the least significant for Abies nordmanniana, but it was of great importance in the distribution of Pinus sylvestris. The most suitable habitats for the studied species in the Caucasus were non-steep slopes with moist soils and humidity climate.

The ecological niches of the studied species largely overlaped in the moisture factor (Fagus orientalis and Carpinus betulus, Abies nordmanniana and Picea orientalis, and Pinus sylvestris and Picea orientalis) and in the topographic factor (Abies nordmanniana and Picea orientalis, Fagus orientalis and Carpinus betulus, and Fagus orientalis and Abies nordmanniana).

According to the Schoener's D index, the ecological niche of Picea orientalis significantly overlaped with the ecological niches of other studied species with the exception of Carpinus betulus. The ecological niche of Carpinus betulus overlapped relatively weakly with the niches of other species with the exception of Fagus orientalis. Carpinus betulus, Fagus orientalis and Pinus sylvestris had the widest ecological niches, while Abies nordmanniana and Picea orientalis had much smallest ecological niches.

The studies were carried out as part of state assignment no. 075-00347-19-00 on the topic "Patterns of the Spatiotemporal Dynamics of Meadow and Forest Ecosystems in Mountainous Areas (Russian Western and Central Caucasus). "

\section{References}

1. J. Franklin, Mapping Species Distributions: Spatial Inference and Prediction (Ecology, Biodiversity and Conservation) (New York, Cambridge University Press, 2010)

2. D. Zurell, J. Engler, Ecological niche modelling (Oxford Scholarship Online, 2019)

3. R.M. Chefaoui, J. Assis, C.M. Duarte, E.A. Serrão, ESTUAR COAST 39, 123-137 (2015)

4. N. Sillero, A.M. Barbosa, INT J GEOGR INF SCI 35(2), 213-226 (2021)

5. J. Elith, C.H. Graham, R.P. Anderson, M. Dudik, et al., Ecography 29(2), 129-151 (2006)

6. S.S. Thakuri, P. Shrestha, M. Deuba, P. Shah, O.P. Bhandari, S. Shrestha, ISPRS Annals of Photogrammetry, Remote Sensing and Spatial Information Sciences, IV-5/W2.P.103-110S (2019)

7. S.J. Phillips, M. Dudík, Ecography 31(2), 161-175 (2008)

8. T. Dube, O. Mutanga, K. Seutloali, S. Adelabu, C. Shoko AFR J AQUAT SCI 40(1), 1-7 (2015) 
9. Y.J. Yi, Y. Zhou, Y.P. Cai, W. Yang, Z.W. Li, X. Zhao, Ecol Indic 92, 40-50 (2018)

10. O. Komori, Sh. Eguchi, Statistical Methods for Imbalanced Data in Ecological and Biological Studies (Springer, 2019, 27-33)

11. R. Levins, Evolution in changing environments. Monographs in population biology (New Jersey, Princeton University Press, 1968)

12. T.W. Schoener, Ecology 49, 704-726 (1968)

13. A.K. Tembotov, E.A. Shebzukhova, F.A. Tembotova, A.A. Tembotov, I.L. Vorokova, Problems of ecology of mountain areas (Maykop, 2001)

14. U.B. Nielsen, J. Xu, O.K. Hansen, Tree Genet. Genomes 16, 66 (2020)

15. H.N. Rasmussen, M. Jensen, J. Frampton, H.-M. Jens, N. Bräuner, NEW FOREST 51, 781-800 (2020)

16. H.N. Rasmussen, B. Veierskov, J. Hansen-Møller, N. Rikke, U.B. Nielsen, J Plant Growth Regul 28, 154166 (2009)

17. K. Nawrot-Chorabik, J. For. Res. 27, 1219-1228 (2016)

18. A. Valdiani, O.K. Hansen, V.K. Johannsen, U.B. Nielsen, Int. J. Environ. Sci. Technol 17, 1425-1438 (2020)

19. J. Xu, O.K. Hansen, I.M. Thomsen, B.U. Nielsen. Booth \& Samuels. Annals of Forest Science 75, 17 (2018)

20. S. Coban, APPL ECOL ENV RES 18(5), 7353-7367 (2020)

21. H. Zengin, M. Özcan, E. Erdoğan, A.S. Değermenci, M.G.N. Aksoy, SEAB2017, 141 (2017)

22. A. Gokturk, H. Tıraş, APPL ECOL ENV RES 18(5), 6163-6179 (2019)

23. S.A. Litvinskaya, V.P. Salina, Geograficheskiye issledovaniya Krasnodarskogo kraya (Krasnodar, 2012)

24. V.V. Akatov, P.V. Akatov, S.V. Mayorov, Izvestiya Rossiyskoy akademii nauk. Seriya geograficheskaya 2, 104-114 (2013)

25. S.M. Bebiya, Sibirskiy lesnoy zhurnal 1, 9-24 (2015)

26. G.Ye. Komin, Zhurnal Sibirskogo federal'nogo universiteta. Seriya: Biologiya 5(1), 4-12 (2012)

27. A.V. Gornov, M.V. Gornova, Ye.V. Tikhonova, N.Ye. Shevchenko, A.I. Kuznetsova, Ye.V. Ruchinskaya, D.N. Tebenkova, Russian Forest Sciences 4, 243-257 (2018)

28. A.F. Komarova, N.V. Kuksina, A.G. Zudkin, Sovr. Probl. DZZ Kosm. 13(5), 157-166 (2016)

29. N.E. Shevchenko, A.P. Geraskina, Ecol. Quest. 30(2), 47-55 (2019)

30. A. Tufekcioglu, S. Güner, F. Tilki, Artvin Çoruh Üniversitesi, Orman Fakültesi Dergisi 9(1-2), 101106 (2008)

31. A. Usta, M. Y1lmaz, Eur J Forest Res March, (2020)
32. H. Inceer, D. Guney, S. Hayirlioglu-Ayaz, O. Melahat, Biologia 64, 1076 (2009)

33. D. Güney, I. Turna, F. Atar, A. Bayraktar, Z. Yahyaoglu, Šumarski list 143, 547-547 (2019)

34. A. Tufekcioglu, S. Güner, F. Tilki, Artvin Çoruh Üniversitesi, Orman Fakültesi Dergisi 9(1-2), 101106 (2008)

35. C. Dülgeroğlu, s1lay Emir, International Conference on Environmental Science and Technology (2015)

36. T. Sariyildiz, M. Küçük, Eur J Forest Res 128, 351360 (2009)

37. H. Akinci, B.F. Erşen, J Entomol. Res. Soc. 18.910, 119-125 (2016)

38. M.Yu. Pukinskaya, D.S. Kessel, K.V. Shchukina, Bot. zhurn. 104(3), 337-362 (2019)

39. I.V. Petrova, S.N. Sannikov, F.A. Tembotova, N.S. Sannikova, V.S.F. Arzaliev, M.Z. Mollaeva, E.V. Egorov, Russ. J. Ecol. 48(6), 524-531 (2017)

40. N.B. Yermakov, Z.I. Abdurakhmanova, I.L. Potapenko, Turczaninowia 22(4), 154-171 (2019)

41.F.A. Tembotova, M.Z. Mollaeva, R.Kh. Pshegusov, Izvestiya Dagestanskogo gosudarstvennogo pedagogicheskogo universiteta. Yestestvennyye i tochnyye nauki 11(4), 55-61 (2017)

42. M.Z. Mollaeva, Izvestiya Samarskogo nauchnogo tsentra Rossiyskoy akademii nauk 17(4-2), 370-375 (2015)

43. M.Z. Mollaeva, F.A. Tembotova, O.E. Cherepanova, S.N. Sannikov, MOSM2018, 030014 (2019)

44. Ch. Aliev, A. Koltunova, M. Kutsev, B. Tuniyev, Turczaninowia 23, 17-31 (2020)

45. D. Dagtekin, E. Şahan, Th. Denk, N. Köse, N. Dalfes, PLoS ONE 15 (2020)

46. D. Dagtekin, E. Şahan, N. Köse, N. Dalfes, Ecology and Evolutionary Biology Symposium Turkey (2018)

47. D. Koç, D. Biltekin, B. Ustaoglu, ARAB J GEOSCI 14(12), 1186 (2021)

48. ENVIronmental Rasters for Ecological Modeling, Available at https://envirem.github.io/ (accessed June 2021)

49. P.O. Title, J.B. Bemmels, Ecography 41(2), 291-307 (2018)

50. S. Le, J. Josse, F.Husson, J Stat Softw 25(1), 1-18 (2008)

51. D. Warren, R. Glor, M. Turelli, Ecography 33, 607$611(2010)$

52. R.G. Allen, L.S. Pereira, D. Raes, M. Smith, FAO Irrigation and drainage paper No. 56. Crop Evapotranspiration (Rome, 1998)

53. Sh.J. Riley, S.D. Degloria, S.D. A. Elliot, Int J Sci Res (Raipur) 5(1-4), 23-27 (1999)

54. S. Gruber, Geomorphometry: Concepts, Software, Applications (Amsterdam, Elsevier, 2009, 121-140)

55. D. Rödder, J.O. Engler, GLOBAL ECOL BIOGEOGR 20(6), 915-927 (2011) 
56. H. Ucarc1, N. Bilir, Mehmet Akif Ersoy Üniversitesi Fen Bilimleri Enstitüsü Dergisi 1, 45-50 (2018)

57. I.R. Rakhmatullina, Z.Z. Rakhmatullin, E.R. Latypov, Prirodoobustroystvo 3, 104-111 (2017)

58. A.P. Isaev, B.Z. Borisov, E.N. Nikiforova, Natural resources of the Arctic and Subarctic 24(3), 121-133 (2019)

59. L. Jensen, J. Lawesson, H. Balslev, M. Forchhammer, Nord. J. Bot. 23, 57-67 (2008)

60. GBIF.org (06 July 2020) GBIF Occurrence Download https://doi.org/10.15468/dl.v2ff6j 